\title{
Resistin increases the expression of NOD2 in mouse monocytes
}

\author{
YI REN, TAOMEI WAN, ZHICAI ZUO, HENGMIN CUI, XI PENG, JING FANG, JUNLIANG DENG, \\ YANCHUN HU, SHUMING YU, LIUHONG SHEN, XIAOPING MA, YA WANG and ZHIHUA REN \\ Sichuan Province Key Laboratory of Animal Disease and Human Health, \\ College of Veterinary Medicine, Sichuan Agricultural University, Chengdu, Sichuan 611130, P.R. China
}

Received January 14, 2016; Accepted January 20, 2017

DOI: $10.3892 /$ etm.2017.4288

\begin{abstract}
Previous studies have indicated that resistin, a type of adipokine, contributes to the development of insulin resistance and type 2 diabetes mellitus, and mediates inflammatory reactions. However, a specific receptor for resistin has not yet been identified. In this study, the relationship between resistin and nucleotide-binding oligomerization domain-like receptors, as well as resistin signal transduction, was examined through transfection, quantitative polymerase chain reaction, western blot analysis and ELISA. The mRNA expression of nucleotide-binding oligomerization domain-containing protein 2 (NOD2), a key immune receptor related to insulin resistance, was significantly increased by resistin treatment at concentrations of 100, 150 and $200 \mathrm{ng} / \mathrm{ml}(\mathrm{P}<0.05, \mathrm{P}<0.01$ and $\mathrm{P}<0.01$, respectively). The mRNA expression of downstream signaling molecules in the NOD2 signaling pathway, receptor-interacting serine/threonine-protein kinase 2 (RIP2; $\mathrm{P}<0.01$ at 6,12 and $24 \mathrm{~h})$ and inhibitor of $\mathrm{NF}-\kappa \mathrm{B}$ kinase subunit beta $(\mathrm{P}<0.01$ at $3,6,12$ and $24 \mathrm{~h})$ were significantly increased by resistin treatment compared with the control. The mRNA expression of key proinflammatory cytokines, tumor necrosis factor $\alpha$, IL (interleukin)- 6 and IL-1 $\beta$, were also significantly increased by resistin treatment compared with the control $(\mathrm{P}<0.01)$. NOD2 knockdown by small interfering RNA (siRNA) significantly decreased the expression of NOD2 and RIP2 $(\mathrm{P}<0.01)$, and there was no significant increase in the levels of cytokines, as compared with treatment with control siRNA. These findings indicate that the inflammatory reaction induced by resistin involves the NOD2-nuclear factor $(\mathrm{NF})-\kappa \mathrm{B}$ signaling pathway. The inhibition of NF- $\mathrm{B}$ significantly decreased the secretion of key inflammatory cytokines $(\mathrm{P}<0.01)$, suggesting that $\mathrm{NF}-\kappa \mathrm{B}$ signaling mechanisms are essential to the resistin-induced inflammatory response.
\end{abstract}

Correspondence to: Professor Zhicai Zuo, Sichuan Province Key Laboratory of Animal Disease and Human Health, College of Veterinary Medicine, Sichuan Agricultural University, 221 Huimin Road, Wenjiang, Chengdu, Sichuan 611130, P.R. China

E-mail: zzcjl@126.com

Key words: resistin, nucleotide-binding oligomerization domain-like receptor, inflammation, obesity

\section{Introduction}

Obesity is considered an epidemic in numerous countries worldwide and is linked to insulin resistance, which constitutes a principal risk factor for type 2 diabetes (1-3). Previous studies have shown that inflammation is a key pathophysiological process linked to obesity, insulin resistance and type 2 diabetes $(4,5)$. Insulin resistance is also associated with chronic low-grade inflammation in vivo, which is largely mediated by activated innate immune cells (6).

Resistin is a cysteine-rich, $12.5-\mathrm{kDa}$ protein that was first identified as a mediator of insulin resistance in obese mice (7-10). Resistin promotes both inflammation and insulin resistance associated with energy homeostasis impairment (11). However, the key molecular mechanisms mediating its effects are unknown. Previous studies have investigated the function of resistin in mouse obesity and diabetes models, and have implicated resistin in the pathogenesis of obesity-mediated insulin resistance and type 2 diabetes $(3,12,13)$. Moreover, it has been reported that resistin is closely associated with inflammation (14-16). Resistin regulates the synthesis and secretion of proinflammatory cytokines such as tumor necrosis factor $\alpha$ (TNF- $\alpha$ ), interleukin-6 (IL-6) and IL-1 $\beta$ in macrophages via a nuclear factor $\kappa \mathrm{B}(\mathrm{NF}-\kappa \mathrm{B})$-dependent pathway $(17-20)$, but the specific receptor of resistin in vivo has not yet been identified. A previous study reported that the resistin-induced inflammatory response may involve the Toll-like receptor 4 (TLR4) signaling pathway (21). However, another study reported that the inflammatory response induced by resistin has no direct link with the TLR4 pathway (22). Other previous reports have stated that resistin is related to the insulin-like growth factor 1 receptor and receptor tyrosine kinase-like orphan receptor 1 (ROR1) (22-24). However, the specific receptor of resistin and its signaling pathway have not yet been identified in vivo.

NOD1 and NOD2 are cytosolic pattern recognition receptors in vivo. Some innate immune receptors are regulated by endogenous molecules, such as TLRs and NODs, which are capable of inducing 'aseptic inflammation' (3). NOD1 and NOD2 induce the recruitment of receptor-interacting serine/threonine-protein kinase 2 (RIP2), which promotes $\mathrm{NF}-\kappa \mathrm{B}-$ mediated proinflammatory gene expression when exposed to signal molecules (25). Previous research showed that activation of NOD1 or NOD2 contributes to insulin resistance and a proinflammatory response (26-28). On this basis, the current study explored the relationship between resistin 
and NOD receptors. The results showed that resistin increased NOD2 expression in RAW 264.7 cells, but had no effect on the expression of NOD1. Resistin also promoted the secretion of inflammatory cytokines via the NF- $\mathrm{KB}$ signaling pathway. These findings may contribute to identifying a specific resistin receptor and understanding the underlying mechanisms of resistin in chronic inflammation and insulin resistance.

\section{Materials and methods}

Cell culture and stimulation. RAW 264.7 mouse monocyte cells (American Type Culture Collection, Manassas, VA, USA) were grown in Dulbecco's modified Eagle medium (Sigma-Aldrich; Merck KGaA, Darmstadt, Germany) supplemented with $10 \%$ fetal calf serum (HyClone; GE Healthcare Life Sciences, Logan, UT, USA), 100 U/ml penicillin, $100 \mathrm{mg} / \mathrm{ml}$ streptomycin (both Beijing Solarbio Science \& Technology Co., Ltd., Beijing, China) and $2 \mathrm{mmol} / \mathrm{l}$ L-glutamine at $37^{\circ} \mathrm{C}$ under $5 \% \mathrm{CO}_{2}$. Cells were incubated with resistin (PeproTech EC Ltd., London, UK) at concentrations of 50,100,150 and $200 \mathrm{ng} / \mathrm{ml}$ for 3, 6, 12 and $24 \mathrm{~h}$ to evaluate the impact of resistin treatment on NOD pathways in RAW 264.7 cells. Cells were stimulated by muramyl dipeptide (20 $\mu \mathrm{g} / \mathrm{ml}$; Sigma-Aldrich; Merck KGaA) or diaminopimelic acid (20 $\mu \mathrm{g} / \mathrm{ml}$; Sigma-Aldrich; Merck KGaA) as a positive control group, and a control group without any treatment was also included. For inhibitor treatment, the specific inhibitor of NF- $\kappa B$, parthenolide (Sigma-Aldrich; Merck KGaA), was used. The cell culture medium was replaced with fresh medium containing inhibitor $(25 \mu \mathrm{M})$ and incubated for $1 \mathrm{~h}$ prior to resistin $(200 \mathrm{ng} / \mathrm{ml})$ treatment.

Small interfering RNA (siRNA) silencing. siRNA duplexes targeting the mouse NOD2 gene (NOD2 siRNA) and non-targeting siRNA (control siRNA) were purchased from Guangzhou Ribobio Co., Ltd. (Guangzhou, China). Transfection of NOD2-siRNA and control siRNA into RAW 264.7 cells was performed using Lipofectamine ${ }^{\circledR} 2000$ transfection reagent (Invitrogen; Thermo Fisher Scientific, Inc., Waltham, MA, USA), according to the manufacturer's guidelines. Transient transfections in RAW 264.7 cells were carried out in 6-well plates, and cells were seeded overnight at $4 \times 10^{5}$ cells per well for $6 \mathrm{~h}$. All transfections were carried out in Opti-MEM (Invitrogen, Thermo Fisher Scientific, Inc.) medium. Cells were incubated at $37^{\circ} \mathrm{C}$ for $24 \mathrm{~h}$ after transfection prior to analysis. Protein and mRNA expression levels of NOD2 were quantified in order to detect the effect of the siRNA.

Determination of cytokine levels. The protein levels of IL-6, TNF- $\alpha$, IL- $1 \beta$ and resistin were measured by sandwich ELISA (R\&D Systems, Inc., Minneapolis, MN, USA) using a pair of mouse antibodies, and expressed in $\mathrm{pg} / \mathrm{ml}$.

RNA isolation and quantitative polymerase chain reaction $(q P C R)$. Messenger RNA (mRNA) expression levels were determined by qPCR. Total RNA was isolated using TRIzol reagent (Invitrogen; Thermo Fisher Scientific, Inc.) according to the manufacturer's instructions. Total RNA $(1 \mu \mathrm{g})$ was reverse transcribed into cDNA using standard reagents (Takara
Biotechnology Co., Ltd., Dalian, China). The cDNA was then submitted to qPCR analysis using specific primer pairs and an SYBR Premix Ex Taq ${ }^{\mathrm{TM}}$ II kit (Takara Biotechnology Co., Ltd.). Sequences of promoter-specific primers (Table I) were designed by Primer Premier 5.0 software (Premier Biosoft International, Palo Alto, CA, USA) and synthesized by BGI Tech Solutions Co., Ltd. (Copenhagen, Denmark). The reaction conditions were set to $1 \mathrm{~min}$ at $95^{\circ} \mathrm{C}$ (first segment, one cycle), $5 \mathrm{sec}$ at $95^{\circ} \mathrm{C}$ and $30 \mathrm{sec}$ at $62^{\circ} \mathrm{C}$ (second segment, 39 cycles). Specific transcripts were confirmed by melting-curve profiles (cooling the sample to $65^{\circ} \mathrm{C}$ and heating slowly to $95^{\circ} \mathrm{C}$ with measurement of fluorescence) at the end of each PCR cycle using a C1000 thermal cycler (Bio-Rad Laboratories, Inc., Hercules, CA, USA). Relative gene expression was defined as a ratio of target gene expression vs. $\beta$-actin gene expression. The results were analyzed using a $2^{-\Delta \Delta \mathrm{Cq}}$ assay (29).

Western blot analysis. Monoclonal antibodies against NOD1 (3545; 1:1,000), NOD2 (sc-30199; 1:800), RIP2 (4982; 1:1,000), NF-кB p65 (8242; 1:1,000) and $\beta$-actin (BA2305; 1:800) were purchased from Cell Signaling Technology, Inc. (Danvers, MA, USA) and horseradish peroxidase (HRP)-conjugated secondary antibody (BA2305; 1:3,000) was purchased from Wuhan Boster Biological Technology, Ltd. (Wuhan, China). Total cytoplasmic and nuclear protein was sequentially extracted using a Cytoplasmic and Nuclear Protein Extraction kit (BestBio, Inc., Shanghai, China), and protein concentrations were calculated using bicinchoninic acid assay kits (Pierce; Thermo Fisher Scientific, Inc., Waltham, MA, USA). Protein lysates were kept at $-20^{\circ} \mathrm{C}$ until used for western blot analysis. Protein lysates were fractionated through 7.5-12\% SDS-PAGE and transferred to PVDF membranes (EMD Millipore, Billerica, MA, USA). The membranes were blocked with 5\% fat-free milk powder at room temperature for $1 \mathrm{~h}$ and immunoblotted overnight at $4^{\circ} \mathrm{C}$ with primary antibodies. Next they there incubated with HRP-conjugated secondary antibody for $1 \mathrm{~h}$ at room temperature. After each step, the membranes were washed 5 times with PBS with Tween for $5 \mathrm{~min}$. Finally, the blots were developed using the enhanced chemiluminescence (ECL) system (GE Healthcare Life Sciences).

Data analysis and statistics. Statistical analysis was performed using SPSS 5 software (SPSS, Inc., Chicago, IL USA). Analysis of variance was used to analyze differences among the groups. Data are expressed as the mean \pm standard error of the mean of three independent experiments. $\mathrm{P}<0.05$ was considered to indicate a statistically significant difference.

\section{Results}

Resistin treatment increases NOD2 expression in RAW 264.7 cells. To explore the relationship between resistin and NOD, the mRNA and protein expression levels of NOD1 and NOD2 were analyzed in RAW 264.7 cells by qPCR and western blot analysis. Cells were incubated with different concentrations of resistin $(50,100,150$ or $200 \mathrm{ng} / \mathrm{ml})$. As shown in Fig. 1A, NOD2 protein expression increased following treatment with resistin, as compared with the control. Furthermore, NOD2 mRNA expression significantly increased following treatment with resistin at concentrations of 100, 150 and $200 \mathrm{ng} / \mathrm{ml}(\mathrm{P}<0.05$, 
Table I. Primers used for quantitative polymerase chain reaction.

\begin{tabular}{lll}
\hline Items & \multicolumn{1}{c}{ Sense (5' to 3') } & Antisense (5' to 3') \\
\hline NOD1 & AGGCATTGAAGGACCACC & AGCATCTCAGCGAAGCAC \\
NOD2 & GCTGTCTTGGGATGTGCT & GGATGAAGGGAGTGAGTGTC \\
RIP2 & CCTCCTCGTGTTCCTTGGC & GGTCCTTGTAGGTTTGGTGCT \\
IKK $\beta$ & GTACACCGTGACCGTTGACT & TCCACTTCGCTCTTCTGCCG \\
Resistin & CTTCCTTGTCCCTGAACTGC & ACGAATGTCCCACGAGCC \\
$\beta$-actin & CTGTCCCTGTATGCCTCTG & ATGTCACGCACGATTTCC
\end{tabular}

NOD, nucleotide-binding oligomerization domain-containing protein; RIP2, receptor-interacting serine/threonine-protein kinase 2; IKK $\beta$, inhibitor of nuclear factor- $\kappa \mathrm{B}$ kinase subunit $\beta$.

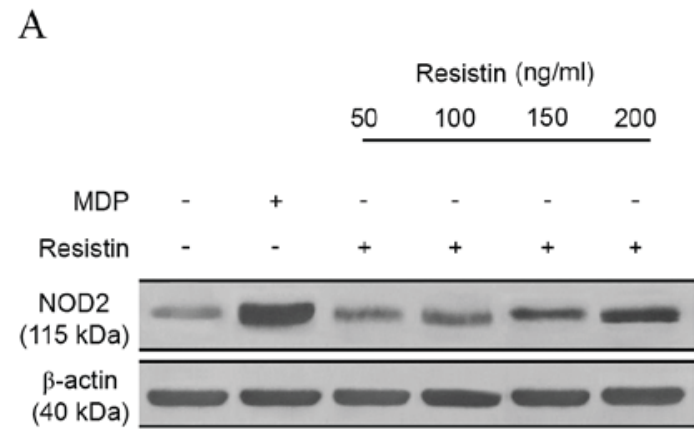

$\mathrm{C}$

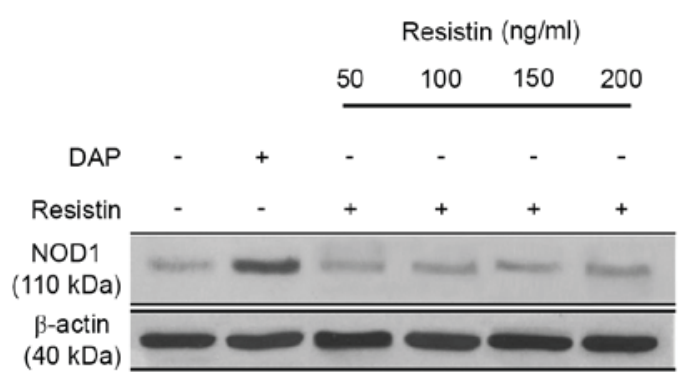

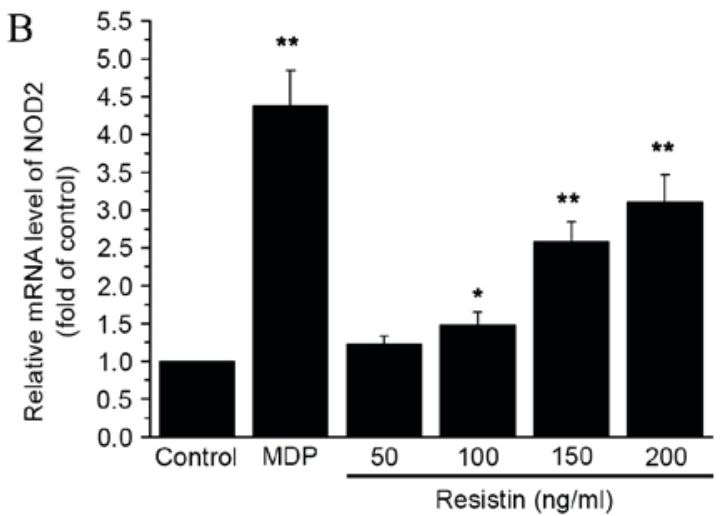

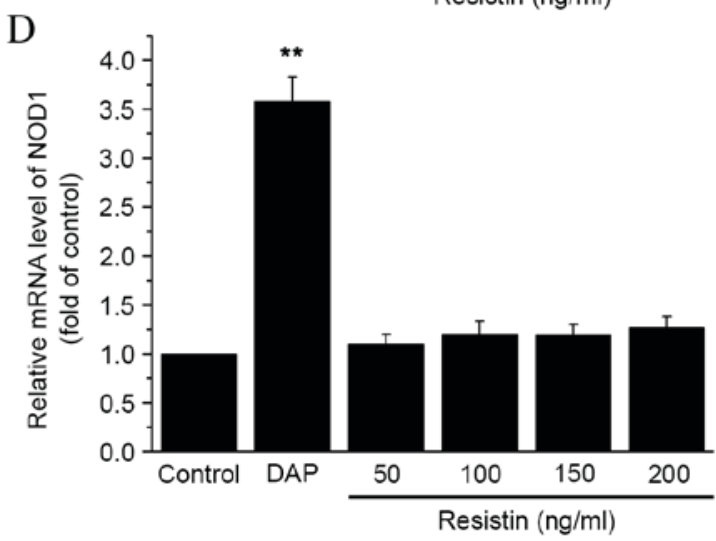

Figure 1. Effect of resistin treatment on the mRNA and protein expression levels of NOD1 and NOD2. RAW 264.7 cells were incubated with MDP $(20 \mu \mathrm{g} / \mathrm{ml})$, DAP $(20 \mu \mathrm{g} / \mathrm{ml})$ or resistin $(50,100,150$ and $200 \mathrm{ng} / \mathrm{ml})$ for $24 \mathrm{~h}$. (A and C) The protein levels of NOD1 and NOD2 were detected by western blot analysis. (B and D) The relative mRNA levels of NOD1 and NOD2. At $24 \mathrm{~h}$ of treatment, qPCR was conducted to measure NOD1 and NOD2 mRNA levels. ${ }^{*} \mathrm{P}<0.05$ and ${ }^{* *} \mathrm{P}<0.01$ vs. control. NOD, nucleotide-binding oligomerization domain-containing protein; MDP, muramyl dipeptide; DAP, diaminopimelic acid; qPCR, quantitative polymerase chain reaction.

$\mathrm{P}<0.01$ and $\mathrm{P}<0.01$, respectively; Fig. 1B), as compared with the control. However, the expression of NOD1 did not change significantly as compared with the control. The expression level of NOD2 reached its peak at $12 \mathrm{~h}$ after adding resistin compared with the control group $(\mathrm{P}<0.01$; Fig. 2$)$. These data indicated that resistin treatment increased the expression of NOD2, but not NOD1.

Resistin treatment activates NOD2-NF- $\kappa B$ pathways. To investigate the potential impact of resistin on NOD2-NF- $\mathrm{B}$ pathways, the expression levels of downstream signaling molecules, RIP2 and inhibitor of $N F-\kappa B$ kinase subunit $\beta$
(IKK $\beta$ ), were determined by qPCR and western blot analysis. The western blot data showed an increase in RIP2 protein expression, and an increase of NF- $\mathrm{BB}$ in the nucleus was also observed (Fig. 2A). At the mRNA level, there was a significant increase in both RIP 2 and IKK $\beta$ expression at 6,12 and $24 \mathrm{~h}$, as compared with the control $(\mathrm{P}<0.01$; Fig. $2 \mathrm{~B})$. Furthermore, we evaluated the effect of resistin treatment on the expression of three key proinflammatory cytokines: TNF- $\alpha$, IL- 6 and IL-1 $\beta$. There was a significant increase in the protein levels of TNF- $\alpha$, IL- 6 and IL-1 $\beta$ as compared with the control $(\mathrm{P}<0.01$, Fig. 2C). These data indicate that the stimulation of resistin activates NOD2-NF- $\kappa$ B pathways. 
A

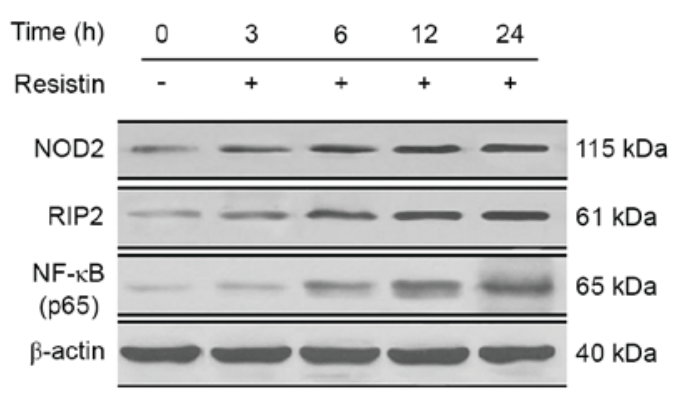

$\mathrm{B}$

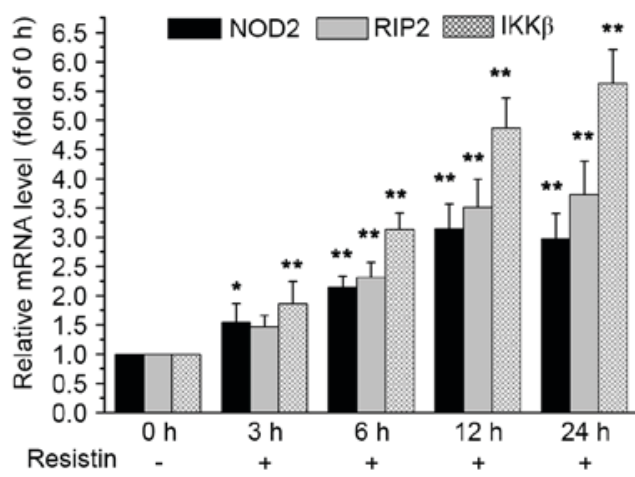

$\mathrm{C}$

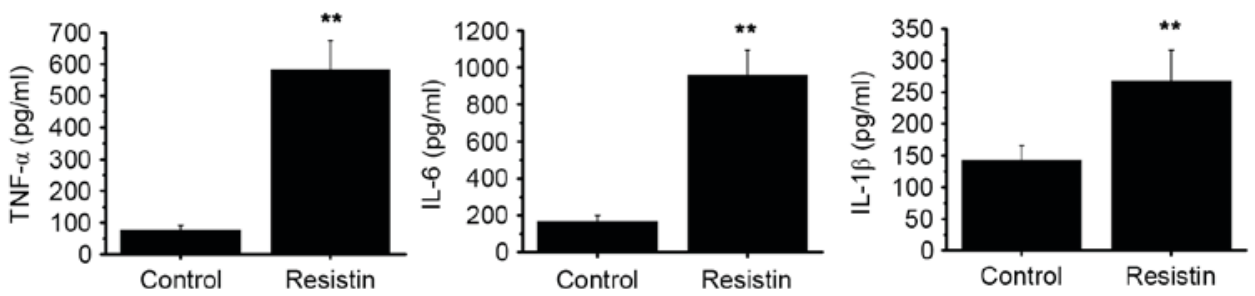

Figure 2. Effect of resistin treatment on NOD2-NF-кB pathways. RAW 264.7 cells were treated with resistin (200 ng/ml) for 0, 3, 6, 12 and 24 h. (A) Protein

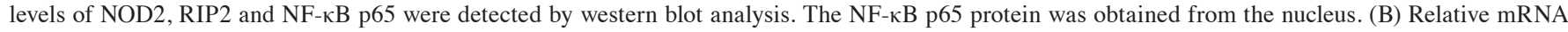
levels of NOD2, RIP2 and IKK $\beta$ were analyzed using qPCR at the end of each experimental period of resistin treatment. mRNA levels at 3, 6, 12 and $24 \mathrm{~h}$ were calculated as a fold change of the mRNA level at $0 \mathrm{~h}$. (C) At the end of the experimental period of resistin treatment, the cell supernatant was collected and the levels of key proinflammatory cytokines (TNF- $\alpha$, IL- 6 and IL-1 $\beta$ ) were detected by ELISA. ${ }^{*} \mathrm{P}<0.05$ and ${ }^{* *} \mathrm{P}<0.01$ vs. control. NOD2, nucleotide-binding oligomerization domain-containing protein $2 ; \mathrm{NF}-\kappa \mathrm{B}$, nuclear factor- $\kappa \mathrm{B}$; RIP2, receptor-interacting serine/threonine-protein kinase 2 ; IKK $\beta$, inhibitor of NF- $\kappa$ B kinase subunit $\beta$; TNF- $\alpha$, tumor necrosis factor $\alpha$; IL, interleukin; qPCR, quantitative polymerase chain reaction.

SiRNA-mediated NOD2 knockdown impairs resistin-induced activation of NOD2 pathways, but has no effect on the nuclear translocation of $N F-\kappa B$. To investigate the potential link between resistin and NOD2-NF- $\kappa$ B proinflammatory pathways and assess the effect of NOD2 on resistin signaling, NOD2-siRNA was used to generate NOD2-deleted RAW 264.7 cells (Fig. 3). Treatment with NOD2-siRNA resulted in a significant decrease in both NOD2 protein level $(\mathrm{P}<0.01$; Fig. 3A) and NOD2 mRNA level ( $\mathrm{P}<0.01$; Fig. $3 \mathrm{C})$, as compared with treatment with control siRNA.

As shown in Fig. 2, treatment of RAW 264.7 cells with resistin increased the expression of RIP $2, N F-\kappa B$ and IKK $\beta$ as well as the release of TNF- $\alpha$, IL- 6 and IL-1 $\beta$. However, as shown in Fig. 3B, NOD2 knockdown reversed the resistin-induced increase in RIP2 protein expression. NOD2 knockdown also significantly decreased the mRNA expression level of RIP2 after resistin treatment compared with the control $(\mathrm{P}<0.01$, Fig. 3C). The expression of IKK $\beta$ and the nuclear translocation of $\mathrm{NF}-\kappa \mathrm{B}$ were not affected (Fig. $3 \mathrm{~B}$ and $\mathrm{C}$ ). No significant changes in cytokine secretion levels were detected by ELISA assay (Fig. 3D).

Resistin induces a proinflammatory effect through the $N F-\kappa B$ pathway. The aforementioned data suggested that resistin induced activation of the $N F-\kappa B$ pathway, and that this was necessary for a resistin-induced inflammatory response. To further evaluate the role of the $\mathrm{NF}-\kappa \mathrm{B}$ pathway in resistin-mediated effects, parthenolide, an inhibitor of $\mathrm{NF}-\kappa \mathrm{B}$, was introduced to the cell cultures $1 \mathrm{~h}$ prior to stimulation with resistin. Inhibiting $\mathrm{NF}-\kappa \mathrm{B}$ resulted in significantly decreased resistin-induced protein expression of TNF- $\alpha$, IL-6 and IL-1 $\beta$ compared with the control group $(\mathrm{P}<0.01$, Fig. 4$)$.
This suggested that the NF- $\kappa \mathrm{B}$ pathway is involved in resistin signaling.

\section{Discussion}

A previous study has shown that resistin promotes both inflammation and insulin resistance (11). However, its specific receptor has not yet been identified, and little is known about the molecular mechanisms mediating resistin effects. In the current study, resistin treatment increased the expression of NOD2, RIP2 and IKK $\beta$ and promoted the nuclear translocation of $\mathrm{NF}-\kappa \mathrm{B}$. This indicated that the resistin-induced inflammatory reaction is induced through the NOD2-NF- $\kappa$ B signaling pathway. It was noted that resistin treatment had no effect on NOD1 expression. SiRNA-mediated NOD2 knockdown attenuated the expression of NOD2 and RIP2 at both mRNA and protein level. Furthermore, the inflammatory reaction induced by resistin was slightly inhibited, which indicated that NOD2-NF- $\kappa$ B pathway is involved in resistin signaling. These findings suggested that there may be a synergistic effect between NOD2 and another receptor for resistin.

Resistin is a member of the resistin-like molecule (RELM) hormone family, which includes RELM $\alpha$ and RELM $\beta$. Resistin and RELM $\beta$ contain an additional cysteine near the amino terminus, and crystal structures of both proteins reveal an unusual multimeric structure. RELM $\beta$ is known to contribute to local immune responses (30). Furthermore, resistin and RELM $\beta$ specifically inhibit insulin action in the liver, resulting in insulin resistance (13).

Until now, four receptors for resistin have been reported: TLR4, an isoform of decorin, ROR1 and adenylyl cyclase-associated protein 1 (CAP1). However, none of these are considered 
A

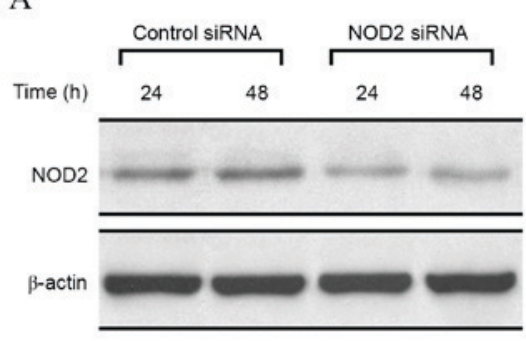

B

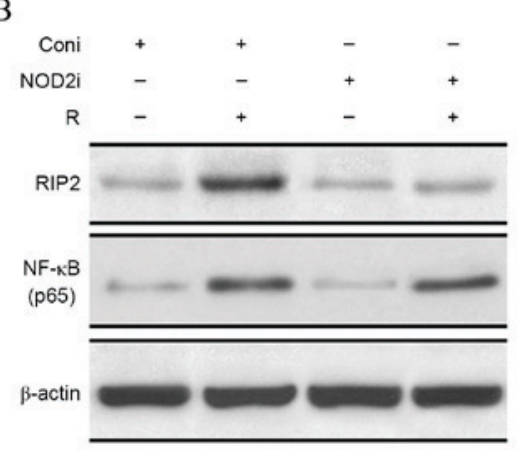

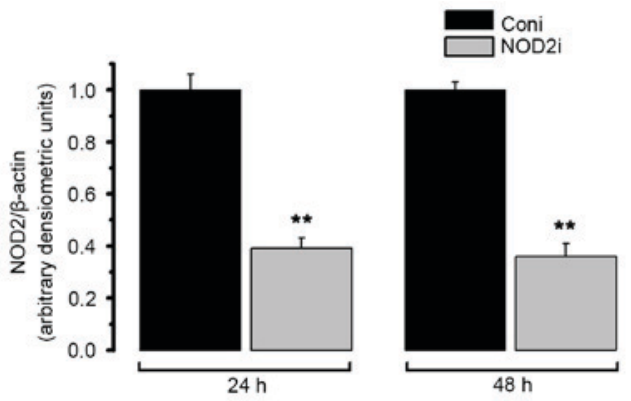

$\mathrm{C}$

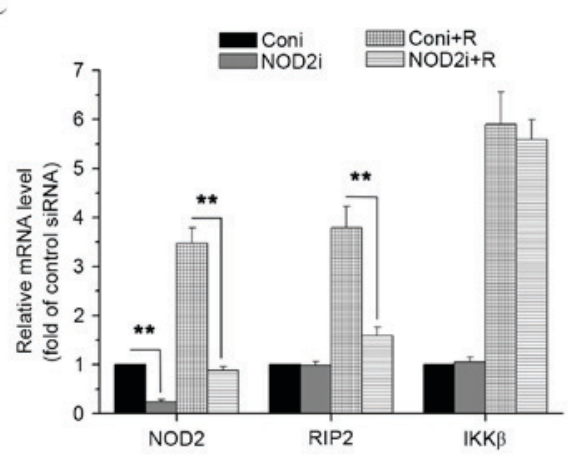

D
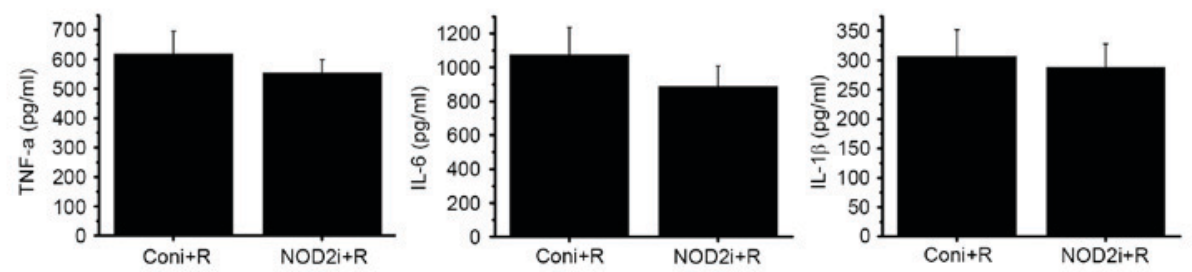

Figure 3. Effect of siRNA-mediated NOD2 knockdown on resistin signaling in RAW 264.7 cells. RAW 264.7 cells were treated with control siRNA or specific siRNA duplexes targeting NOD2. Proteins and RNA were then extracted from the cells for western blot analysis and qPCR. (A) Western blot analysis of NOD2 content in control and NOD2 siRNA-treated cells. The results are expressed as the ratio of NOD2/ $\beta$-actin. (B) Western blot analysis of the expression level of RIP2, and the NF-kB p65 protein level within the nucleus, in the presence or absence of resistin $(200 \mathrm{ng} / \mathrm{ml}$ for $24 \mathrm{~h})$ in RAW 264.7 cells titrated with control or NOD2 siRNA. (C) Relative mRNA levels of NOD2, RIP2 and IKK $\beta$ in the presence or absence or resistin ( $200 \mathrm{ng} / \mathrm{ml}$ for $24 \mathrm{~h})$ in RAW $264.7 \mathrm{cells}$ titrated with control or NOD2 siRNA were measured by qPCR. (D) Protein level of TNF- $\alpha$, IL-6 and IL-1 $\beta$ in each group were detected by ELISA. "** $<<0.01$ vs. control.

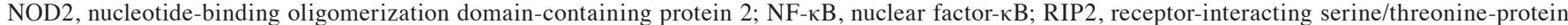
kinase 2; IKK $\beta$, inhibitor of NF-KB kinase subunit $\beta$; TNF- $\alpha$, tumor necrosis factor $\alpha$; IL, interleukin; qPCR, quantitative polymerase chain reaction; siRNA, small interfering RNA; coni, control siRNA; NOD2i, NOD2-siRNA; R, resistin.
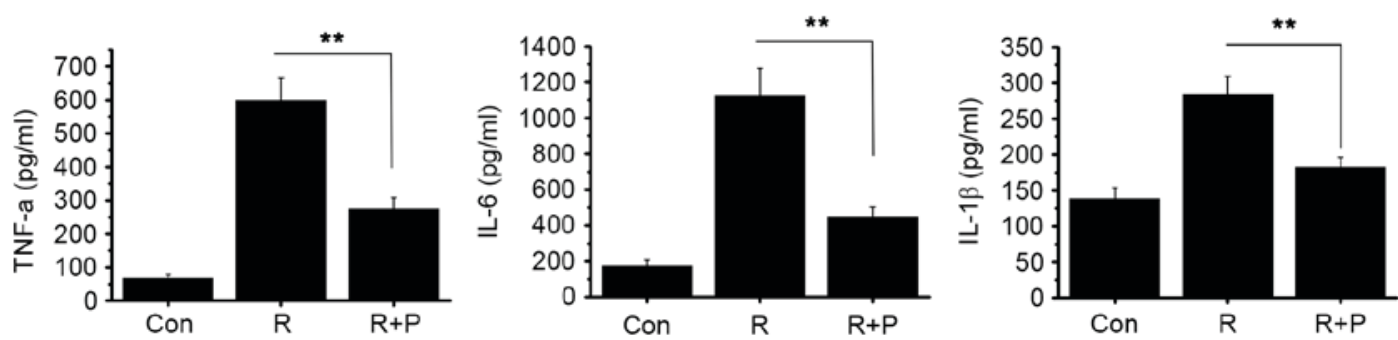

Figure 4. Effect of NF-кB inhibition on the resistin-induced inflammation response. RAW 264.7 cells were treated with a specific inhibitor of the NF- $\mathrm{kB}$ signaling pathway (parthenolide) prior to stimulation with resistin. Cell cultures were examined by ELISA for the expression of cytokines TNF- $\alpha$, IL- 6 and

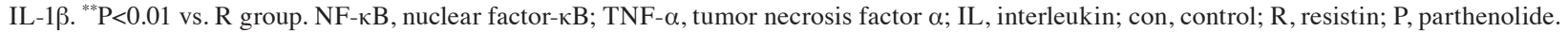

to be the specific receptor of resistin in vivo (22). Previous research found no evidence for a direct interaction between resistin and TLR4 in a biochemical binding assay (22). Decorin and ROR1 were only expressed at low levels in human monocytes and neither expression level increased following resistin stimulation (22). Therefore, the inflammatory response induced by resistin was not directly related to TLR4, ROR1 or decorin. Furthermore, the study found that resistin could combine with CAP1, but as CAP1 lacks a transmembrane domain, it is not clear how the signal would be transmitted to the cell interior (22).

NOD2 is a key receptor in the inflammation reaction, which has been associated with insulin resistance in previous studies $(26,28)$. These physiological functions are similar to those of resistin, therefore the links between resistin and NODs were investigated in the current study. Resistin treatment 
significantly increased the expression level of NOD2, and the resistin-induced inflammatory response was found to be induced at least partly through the NOD2-NF- $\mathrm{kB}$ signaling pathway.

$\mathrm{NF}-\mathrm{kB}$ is a key transcription factor in the process of inflammatory reactions, and many inflammatory cytokines are regulated by it, including TNF- $\alpha$, IL- 6 and IL-1 $\beta(31,32)$. In the current study, resistin treatment promoted NF- $\mathrm{kB}$ translocation into the nucleus and significantly increased the levels of key inflammatory cytokines. Treatment with a specific inhibitor of NF- $\mathrm{KB}$ confirmed that resistin-induced signals are mediated through NF- $\mathrm{KB}$ signaling mechanisms. These findings are consistent with recent studies, which have reported that NF- $\kappa B$ signaling mechanisms are essential for the resistin-induced inflammatory response.

In summary, the current study demonstrated that resistin treatment increases NOD2 expression and that the inflammatory response induced by resistin involves the NOD2-NF- $\mathrm{KB}$ signaling pathway.

\section{Acknowledgements}

This study was supported financially by the Natural Science Foundation of Science and Technology Department of Sichuan Province (grant no. 2013NZ0032).

\section{References}

1. Kahn BB and Flier JS: Obesity and insulin resistance. J Clin Invest 106: 473-481, 2000.

2. Wellen KE and Hotamisligil GS: Obesity-induced inflammatory changes in adipose tissue. J Clin Invest 112: 1785-1788, 2003.

3. Zhao L, Kwon MJ, Huang S, Lee JY, Fukase K, Inohara N and Hwang DH: Differential modulation of Nods signaling pathways by fatty acids in human colonic epithelial HCT116 cells. J Biol Chem 282: 11618-11628, 2007.

4. Ferroni P and Basili S, Falco A and Davì G: Inflammation, insulin resistance, and obesity. Curr Atheroscler Rep 6: 424-431, 2004.

5. Steinberg GR: Inflammation in obesity is the common link between defects in fatty acid metabolism and insulin resistance. Cell Cycle 6: 888: 894, 2007

6. Heilbronn LK and Campbell LV: Adipose tissue macrophages, low grade inflammation and insulin resistance in human obesity. Curr Pharm Des 14: 1225-1230, 2008.

7. Mooradian AD: Obesity: A rational target for managing diabetes mellitus. Growth Horm IGF Res 11 (Suppl A): S79-S83, 2001.

8. Patel SD, Rajala MW, Rossetti L, Scherer PE and Shapiro L: Disulfide-dependent multimeric assembly of resistin family hormones. Science 304: 1154-1158, 2004.

9. Lin J, Choi YH, Hartzell DL, Li C, Della-Fera MA and Baile CA: CNS melanocortin and leptin effects on stearoyl-CoA desaturase-1 and resistin expression. Biochem Biophys Res Commun 311: 324-328, 2003.

10. Strausberg RL, Feingold EA, Grouse LH, Derge JG, Klausner RD, Collins FS, Wagner L, Shenmen CM, Schuler GD, Altschul SF, et al: Generation and initial analysis of more than 15,000 full-length human and mouse cDNA sequences. Proc Natl Acad Sci USA 99: 16899-16903, 2002.

11. Mojiminiyi $\mathrm{O}$ and Abdella N: Associations of resistin with inflammation and insulin resistance in patients with type 2 diabetes mellitus. Scand J Clin Lab Invest 67: 215-225, 2007.

12. Muse ED, Obici S, Bhanot S, Monia BP, McKay RA, Rajala MW, Scherer PE and Rossetti L: Role of resistin in diet-induced hepatic insulin resistance. J Clin Invest 114: 232-239, 2004.
13. Banerjee RR, Rangwala SM, Shapiro JS, Rich AS, Rhoades B, Qi Y, Wang J, Rajala MW, Pocai A, Scherer PE, et al: Regulation of fasted blood glucose by resistin. Science 303: 1195-1198, 2004.

14. Reilly MP, Lehrke M, Wolfe ML, Rohatgi A, Lazar MA and Rader DJ: Resistin is an inflammatory marker of atherosclerosis in humans. Circulation 111: 932-939, 2005.

15. Senolt L, Housa D, Vernerová Z, Jirásek T, Svobodová R, Veigl D, Anderlová K, Müller-Ladner U, Pavelka K and Haluzík M: Resistin in rheumatoid arthritis synovial tissue, synovial fluid and serum. Ann Rheum Dis 66: 458-463, 2007.

16. Filková M, Haluzík M, Gay S and Šenolt L: The role of resistin as a regulator of inflammation: Implications for various human pathologies. Clin Immunol 133: 157-170, 2009.

17. Bokarewa M, Nagaev I, Dahlberg L, Smith U and Tarkowski A: Resistin, an adipokine with potent proinflammatory properties. J Immunol 174: 5789-5795, 2005.

18. Wellen KE and Hotamisligil GS: Obesity-induced inflammatory changes in adipose tissue. J Clin Invest 112: 1785-1788, 2003.

19. Olefsky JM and Glass CK: Macrophages, inflammation, and insulin resistance. Annu Rev Physiol 72: 219-246, 2010.

20. Silswal N, Singh AK, Aruna B, Mukhopadhyay S, Ghosh S and Ehtesham NZ: Human resistin stimulates the pro-inflammatory cytokines TNF-alpha and IL-12 in macrophages by NF-kappaB-dependent pathway. Biochem Biophys Res Commun 334: 1092-1101, 2005.

21. Tarkowski A, Bjersing J, Shestakov A and Bokarewa MI: Resistin competes with lipopolysaccharide for binding to toll-like receptor 4. J Cell Mol Med 14: 1419-1431, 2010.

22. Lee S, Lee HC, Kwon YW, Lee SE, Cho Y, Kim J, Lee S, Kim JY, Lee J, Yang HM, et al: Adenylyl cyclase-associated protein 1 is a receptor for human resistin and mediates inflammatory actions of human monocytes. Cell Metab 19: 484-497, 2014.

23. Boström EA, Svensson M, Andersson S, Jonsson IM, Ekwall AK, Eisler T, Dahlberg LE, Smith U and Bokarewa MI: Resistin and insulin/insulin-like growth factor signaling in rheumatoid arthritis. Arthritis Rheum 63: 2894-2904, 2011.

24. Sánchez-Solana B, Laborda J and Baladron V: Mouse resistin modulates adipogenesis and glucose uptake in 3T3-L1 preadipocytes through the ROR1 receptor. Mol Endocrinol 26: 110-127, 2012.

25. Inohara N, Koseki T, Lin J, del Peso L, Lucas PC, Chen FF, Ogura Y and Núñez G: An induced proximity model for NF-kappa B activation in the Nod1/RICK and RIP signaling pathways. J Biol Chem 275: 27823-27831, 2000.

26. Tamrakar AK, Schertzer JD, Chiu TT, Foley KP, Bilan PJ, Philpott DJ and Klip A: NOD2 activation induces muscle cell-autonomous innate immune responses and insulin resistance. Endocrinology 151: 5624-5637, 2010.

27. Zhao L, Hu P, Zhou Y, Purohit J and Hwang D: NOD1 activation induces proinflammatory gene expression and insulin resistance in 3T3-L1 adipocytes. Am J Physiol Endocrinol Metab 301: E587-E598, 2011.

28. Schertzer JD and Klip A: Give a NOD to insulin resistance. Am J Physiol Endocrinol Metab 301: E585-E586, 2011.

29. Livak KJ and Schmittgen TD: Analysis of relative gene expression data using real-time quantitative PCR and the 2(-Delta Delta C(T)) Method. Methods 25: 402-408, 2001.

30. He W, Wang ML, Jiang HQ, Steppan CM, Shin ME, Thurnheer MC, Cebra JJ, Lazar MA and Wu GD: Bacterial colonization leads to the colonic secretion of RELMbeta/FIZZ2, a novel goblet cell-specific protein. Gastroenterology 125: 1388-1397, 2003.

31. Cho SY, Park SJ, Kwon MJ, Jeong TS, Bok SH, Choi WY, Jeong WI, Ryu SY, Do SH, Lee CS, et al: Quercetin suppresses proinflammatory cytokines production through MAP kinases and NF-kappaB pathway in lipopolysaccharide-stimulated macrophage. Mol Cell Biochem 243: 153-160, 2003.

32. Karin $M$ and Delhase M: The I kappa B kinase (IKK) and NF-kappa B: Key elements of proinflammatory signalling. Semin Immunol 12: 85-98, 2000. 